\title{
THE STRUGGLE FOR THE STORY IN POLITICAL DISPUTES. THE CASE OF THE 9N 2014 PARTICIPATION PROCESS
}

\section{Pugna por el relato en los contenciosos políticos. EI caso del proceso participativo del $9 \mathrm{~N}$ de 2014}

\section{Òscar Coromina}

Nota: Este artículo se puede leer en español en:

http://www.elprofesionaldelainformacion.com/contenidos/2017/sep/10_esp.pdf

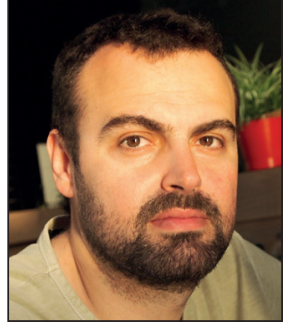

Òscar Coromina is an associate professor and researcher at the Department of Audiovisual Communication and Advertising at Universitat Autònoma de Barcelona where he has been a faculty member since 2008 and has as a professional digital marketing activity in which accumulates more than 15 years of experience. He coordinates the master's degree in Digital Marketing and Communication and is a member of the Research Group on Image, Sound and Synthesis (Griss). His dissertation was about the mediation in Twitter of political disputes. More broadly, his research interests lie in the area of digital culture, with a focus on social media and digital methods.

http://orcid.org/0000-0002-6306-4154

Universitat Autònoma de Barcelona, Departament de Comunicació Audiovisual i Publicitat Campus de la UAB, Edifici I. 08193 Bellaterra (Barcelona), Spain oscar.coromina@uab.cat

\begin{abstract}
Social networks provide new mechanisms for participating in politics and it has been argued that they favor debate, citizen empowerment, and propel democratic changes. This is crucial at a time when forms of political organization, such as parties or unions, have lost their effectiveness. Beyond the debate about the capacity of social networks to incite change and its influence on the outcome of electoral contests, these platforms have become fundamental in the mediatization of politics by turning users into key players in setting the agenda and building the story around politics. This article analyzes a collection of 2,385,396 tweets from the participatory process in Catalonia on November 9, 2014.
\end{abstract}

\section{Keywords}

Twitter; Political communication; Digital methods; Social platforms; Social networks; Social media.

\section{Resumen}

Las redes sociales proporcionan nuevos mecanismos para participar en la política y se ha argumentado que favorecen el debate, el empoderamiento ciudadano y la profundización democrática. Este hecho resulta crucial en un momento en el que formas de organización política como partidos o sindicatos pierden efectividad. Más allá del debate sobre la capacidad de las redes sociales para provocar el cambio y su influencia en el desenlace de contiendas electorales, estas plataformas son fundamentales en la mediatización de la política y convierten a los usuarios en actores clave a la hora de marcar la agenda pública y construir el relato de los acontecimientos políticos. Este artículo toma como caso de estudio la conversación en Twitter alrededor del proceso participativo del 9 de noviembre de 2014 en Cataluña y basa su análisis en una colección de 2,385,396 tweets.

\section{Palabras clave}

Twitter; Comunicación política; Métodos digitales; Plataformas sociales; Redes sociales; Medios sociales.

Coromina, Òscar (2017). "The struggle for the story in political disputes. The case of the 9N participation process". EI profesional de la información, v. 26, n. 5, pp. 884-893. 


\section{Introduction}

\subsection{Construction of political reports on social platforms}

In the current communications ecosystem, social platforms have certain characteristics that distinguish them significantly from traditional media: the role of the user as a creator and distributor of content. In the context of political communication, the potential of social platforms is particularly significant as they can facilitate the ability of users to become active political subjects opening up processes of citizen empowerment and a profound sense of democracy (Casero-Ripollés, 2017). This becomes especially important when the traditional forms of political organization such as political parties and trade unions lose their effect as elements of cohesion (Bennet; Segerberg, 2012).

In recent years several protest movements have used social platforms to construct reports of events and disseminate them on the local and international level. This is the case of the protests against the electoral results in Iran in 2009 (Bruns; Etham, 2009), the Arab spring demonstrations in Egypt and Tunisia (Lotan et al., 2011; Papacharissi; De-Fatima-Oliveira, 2012), and even the $15 \mathrm{M}$ movement in Spain (Bennet; Segerberg, 2012; Borge-Holthoefer et al., 2011; Casero-Ripollés; Feenstra, 2012).

Although users have acquired a much more significant role in framing the media agenda and its interpretation before, during, and after political campaigns, the narrative that exists around politics has emerged from a hybrid system in which traditional and new media sit side by side. In this new scenario, traditional users and actors collaborate in the task of searching for and disseminating the events that are included in a media flow that is highly influenced by conflict, competition, and partisanship (Chadwick, 2011). The report that is propagated through the media is therefore a project in which a multitude of actors participate to reorganize communication flows, share information, and create frames of interpretation. This process has a lot in common with the model of constant negotiation that has been used to describe relations between journalists and politicians (Casero-Ripollés, 2008).

From this process, which may be described as a dialogue, a negotiation or even a fight, interpretative frames used to capture and disseminate the report emerge. Framing involves selecting some aspects of reality and emphasizing them in the message to promote a certain definition, interpretation, assessment, and even a course of action in relation to the subject in question (Entman, 1993). Framing is especially important in the context of political communication since it is a key factor for guiding attention to certain aspects and deviating it from others, fostering different reactions from the public. Social platforms offer other mechanisms to develop and consolidate these interpretative frames such as hashtags and other forms of tagging information. These mechanisms acquire importance as they facilitate collaboration among many different types of actors (activists, members of the public, journalists, politicians, etc.) who intervene independently but are connected through network structures (Meraz; Papacharissi, 2013; Casero-Ripollés, 2015).
Similarly, network communication can explain the way gatekeeping works, with gatekeeping being understood as the process of selecting events to be included in the news flow, thus allow then to appear in a particular medium (McQuail, 1994). While in traditional media gatekeeping is an organic function carried out by a small number of professionals (Villafañe; Bustamante; Prado, 1987), on social platforms this process takes place in a networked way. Items included in the narrative expressed using frames are also selected, filtered, and disseminated by users (Papacharissi, 2015). Networked framing and networked gatekeeping are used to describe the communication processes and media flows which occur in different protests, the establishment of dominant narratives, and the appearance of different opinion leaderships (Papacharissi, 2015).

The narrative that exists around politics has emerged from a hybrid system in which traditional and new media sit side by side

\subsection{Twitter and the mediatization of political affairs}

Twitter appeared in 2006 and was presented as a service with functions and characteristics that placed it at the crossroads of instant messaging services, blogs, and social networks combined on a single platform (Boyd; Golder; Lotan, 2010; Van-Dijck, 2011). One of its main characteristics is that it does not have a predetermined function in relation to published content and today it is used to publish spontaneous thoughts, take part in conversations with other users, share information and take part in cooperative processes for a wide range of purposes such as political communication, journalism, events monitoring, and interpersonal relations.

Other distinguishing features of Twitter are the adoption of different objects and conventions which make publication on the platform more dynamic such as retweets, tags, replies, and hashtags. Of all these we want to focus on hashtags, which have become one of the most used resources for coordinating a conversation on a specific topic or event (Bruns; Stieglitz, 2012; Bruns; Burguess, 2011). As stories of political events unfold, hashtags are especially important as they are an essential tool for articulating the dialogue and even moving it into action (Bruns; Burguess, 2011; Small, 2011; Aragón et al., 2013). This resource is therefore crucial for organizing audiences on a certain political position, since they are the main resource on the platform for grouping tweets thematically. Hashtags also provide the space where framing is decided in relation to controversial issues, as demonstrated by the fact that they often become the object of (counter) propagandistic actions where they are "hijacked" with the intention of promoting the publication of messages that are ideologically opposite to the original (Hadgu; Garimella; Weber, 2013).

Beyond those functions, hashtags are also important in the context of Twitter research since they are especially useful for identifying and isolating tweets related to a specific 
topic, while allowing different qualitative and quantitative methods to be used to analyze the content in more detail as well as to observe how the narrative is articulated in the network (Highfield, 2012).

\subsection{The participative process of $9 \mathrm{~N}$}

In recent years, Catalonia has seen how discussion over the need to change its political status has become a central theme for political debate. This demand has obtained considerable success in involving a large part of the public, civil organizations, and political parties, resulting in large public turnouts in the streets and a large participation by the social platforms. This article uses the participative process on the political future of Catalonia, which took place on November 9, 2014, as a study case.

\section{Research questions}

This study is organized around three research questions:

What are the main traits which distinguish the narrative of the political process of November 9 on Twitter?

What were the central frames in the narrative of the political process of November 9 on Twitter?

Which strategies were used for the construction of the narrative?

\section{Methodology}

The methodology used to answer the research questions is organized into three processes: data extraction, hashtag networks, and hashtag categorization.

\subsection{Extraction}

We chose the Twitter search API for the data extraction as it offers a non-intrusive and automatized method of making a collection of tweets. To access our environment we used DMI-TCAT software -a tool developed by Erik Borra and Bernhard Rieder designed to store and analyze tweets for the purpose of carrying out research in the social and human sciences (Borra; Rieder, 2014).

To articulate the tweets on which to carry out the analysis we captured those with the keywords "9N" or "9N2014", between September 11 and 14 November, 2014. The keywords " $9 \mathrm{~N}$ " and "9N2014" were selected because they were widely used as hashtags in tweets related to the consultation and were, a priori, free of any ideological bias.

As a result of the extraction process a collection of data was obtained comprised of 2,385,396 tweets published by 303,366 different users. Because that the extraction process lasted a little over two months, it was decided to observe the publication dynamics over that period. Figure
1 shows the dates and number of tweets published. Publication activity did not take place uniformly and there were different peaks signaling the times when Twitter debate was more intense. These peaks coincide with some of the most important events in the participative process of $9 \mathrm{~N}$.

Given the high number of tweets published during the extraction period we opted to limit the research to the period of November 4-14. As well as limiting and simplifying the process of analysis, this choice also meant that we could identify different periods in the participative process:

- November 4 to 8. Days before the participative process marked by the second suspension of the Constitutional Court (November 4).

- November 9. Day of the participative process.

- November 10 to 14. Days following the participative process.

\subsection{Hashtag networks}

For each of the three periods we generated networks in which, out of all the messages' content, we only used the hashtags. These corresponded to the nodes of the network and the edges connecting the hashtags represented the number of hashtags in the same tweet. The name of this type of network and its conceptualization follow the discipline of Actor-Network Theory and, more specifically co-word analysis, which is an analytical method designed to identify and visualize the actors and themes related to a particular controversial matter from the co-occurrence in the text of different words that synthesize, signal, and connect the theme defining the problems analyzed (Callon et al., 1983). Coword analysis is therefore a technique for analyzing content which, rather than being based on the assignment of categories to the elements, captures the relationships between the words that represent the links between the concepts, the ideas, and the physical objects that they describe (Danowski, 2009).

Methodologically, the operation of analyzing the hashtags using networks has significant consequences. On the one 
hand it allows the visualization of those networks and on the other it opens the door to using different indicators and metrics used to describe the structural properties of the networks.

To carry out both, we used the Gephi software (Bastian; Heymann; Jacomy, 2009). The spatial distribution of the nodes was done using the Force Atlas 2 algorithm whose function is to distribute the different nodes so that the edges act as forces of attraction and the nodes as forces of repulsion (Jacomy et al., 2011). This means that the hashtags that occurred recurrently in a tweet are positioned closer and those which do not share links occupy positions further away.

Hashtags provide the space where framing is decided in relation to controversial issues

As far as the possibility of calculating metrics and statistics referring to the structural characteristics of the network was concerned, we used betweenness centrality because of its capacity to reflect the centrality of a node in the network. That way themes, events and most central positionings can be reflected in the narrative of $9 \mathrm{~N}$ on Twitter, understanding centrality not as an intermediate point between two ideologically opposed positions but as the terms that the debate and conversation revolves around. A total of 25 hashtags were identified with a higher value of betweenness centrality for each of the time segments analyzed.

Betweenness centrality is also the indicator used to produce the network visualizations. It was used to color the nodes in a graduated range from blue to red with yellow in the middle, with blue the color of the hashtags with the lowest level of betweenness centrality and red the color of the most central elements. The size of the circumferences, representing the nodes, also correspond to this indicator and the labels, the content of the hashtag.

To facilitate the decoding and interpretation of the visualizations in network form (figures 2, 3, and 4) only the 25 hashtags with the highest indices of centrality are shown and the rest are represented as a circle to show the size and structure of the network. The exception to this rule is figure 5 which shows a zoom of one of the networks to display the content of a group of hashtags.

The analysis was completed with the scrutiny of the data base with the aim of contextualizing the use of certain hashtags and tracing their origin. For that reason the sections of this block of analysis reproduce the textual content of some tweets.

\subsection{Categorization of the hashtags}

In addition to the analysis of the networks, we classified the 25 most central hashtags for each of the periods into three categories that identify the main function performed in the tweets.

- Thematic: Includes those hashtags whose main function was the topical demarcation of the content of the tweets, but where we were unable able to deduce the "political" use of the hashtag from its message.

- Campaign: Hashtags which have been identified as part of a campaign supporting one of the options represented in the political debate.

- Media: Groups together the hashtags created ad hoc by TV or radio channels and programs with the aim of opening up a channel of participation by their audiences while simultaneously giving visibility to the content.

\section{Results}

The calculation of the betweenness centrality in the network of hashtags allows us to distinguish 47 different expressions in the set of the top 25 for each of the time segments analyzed. This means that several hashtags appear in different 'top 25s' and denote a more regular and prolonged use over time.

Table 1 shows the number of hashtags in each category and the frequency with which they appear in the tweets. It can be seen that most of the hashtags are related to the campaign activity in terms of the number of different hashtags used and, especially, in terms of the frequency with which they appear in the tweets. This is a good indicator of the tone and the terms in which the mediation of $9 \mathrm{~N}$ took place, and is clearly marked by intense campaign activity. The hashtags related to media spaces are fewer in terms of variety but greater than those whose function was a topical demarcation. This may be attributed to the fact that the dissemination of media hashtags is more centralized and organized.

\subsection{From November 4 th to November 8 th}

As can be seen in Table 2, many of the tags referred to different campaigns to promote participation and the most intensive come from civil entities in favor of independence (17 out of 25). This is the case of \#votarepertu, \#votarépertu, and \#catalansreadytovote. The first two hashtags correspond to motivate Twitter users publically announce the name of a person to whom they intended to dedicate their vote. Analysis of these tweets shows that 3,145 different users put \#votarépertu and 2,696 \#votarepertu, from November 4-8. This campaign began weeks before the period represented in the hashtags network. The persistence of these hashtags over more than 10 days, the volume of tweets published, and the high index of centrality demonstrate the great success of the initiative.

Similarly, \#catalansreadytovote corresponds to a campaign driven by the same entities to broadcast the Catalan case outside the borders of Spain, as seen in the first tweet of the collection of tweets using this hashtag which was published by the user @araeslhora on November 3 6:36 PM

Table 1 . Hashtags by category

\begin{tabular}{|l|c|c|}
\hline \multicolumn{1}{|c|}{ Category } & Hashtags & Frequency \\
\hline Campaign & 23 & 239,585 \\
\hline Thematic & 19 & 43,718 \\
\hline Media & 5 & 60,339 \\
\hline Total & 47 & 343,702 \\
\hline
\end{tabular}


Alerta: Ensenyem el nostre vot al món! Fes-te una foto amb la papereta del $9 \mathrm{~N}$ i comparteix-la a \#CatalansReadyToVote!

http://t.co/Oa6WIL7wXa

(Alert: Let's show the world our vote! Take a selfie with the $9 \mathrm{~N}$ ballot slip and share it to \#CatalansReadyToVote!)

As the tweet makes clear, the objective of the initiative is to involve Twitter users in the dissemination of the $9 \mathrm{~N}$ cause on an international level. In that sense, a good indicator of the capacity of these hashtags for propagating ideas is that they reach the category of trending topic - a guarantee of greater visibility. One tweet published by the user @assembleasmxi on November 4, 1:07 PM, illustrates the achievement of that challenge:

\#CatalansReadyToVote ja és trending topic mundial un altre cop. La quantitat de periodistes internacionals acreditats el \#9N2014, en augment.

(\#CatalansReadyToVote is a world trending topic again. The number of accredited international journalists using \#9N2014 on the increase.)

In figure 2, which represents the network of hashtags for the period, it can be clearly seen how the center of the graph is occupied by a network of different expressions and slogans of support for the independentist agenda, with no tags in the top 25 displaying the counter ideology. It can also be observed that \#tc occupies an important position and this can be related to the second suspension of the Constitutional Court (Tribunal Constitucional) in the consultation process. Tags denoting calls for mobilization and disobedience: \#9Ndesobeïm and \#cassolada.
Table 2. Top 25 hashtags (04/11 - 08/11)

\begin{tabular}{|c|c|c|c|c|}
\hline Hashtag & Frequency & Users & $\begin{array}{c}\text { Betweenness } \\
\text { centrality }\end{array}$ & Category \\
\hline catalansreadytovote & 20,345 & 10,167 & $1,554,559$ & Campaign \\
\hline sisi & 10,097 & 6,061 & $1,293,189$ & Campaign \\
\hline araeslhora & 9,702 & 6,084 & $1,166,960$ & Campaign \\
\hline catalunya & 4,018 & 3,055 & $1,023,075$ & Thematic \\
\hline sísí & 10,896 & 6,481 & $1,012,647$ & Campaign \\
\hline cassolada & 13,102 & 6,789 & 826,672 & Campaign \\
\hline votarem & 8,501 & 5,347 & 758,642 & Campaign \\
\hline votarepertu & 3,959 & 2,696 & 467,324 & Campaign \\
\hline omplimlesurnes & 7,522 & 4,145 & 432,302 & Campaign \\
\hline volemvotar & 3,677 & 2,765 & 424,495 & Campaign \\
\hline barcelona & 2,184 & 1,734 & 378,796 & Thematic \\
\hline araéslhora & 5,728 & 3,813 & 297,585 & Campaign \\
\hline debat9Ntv3 & 4,899 & 2,581 & 291,852 & Media \\
\hline todosavotar & 8,126 & 4,590 & 260,216 & Campaign \\
\hline españa & 1,382 & 1,005 & 236,088 & Thematic \\
\hline catalonia & 2,005 & 1,435 & 218,498 & Thematic \\
\hline cataluña & 1,791 & 1,551 & 209,027 & Thematic \\
\hline 9Ndesobeïm & 3,094 & 2,181 & 182,428 & Campaign \\
\hline tc & 1,139 & 918 & 179,906 & Thematic \\
\hline independencia & 1,384 & 806 & 169,435 & Campaign \\
\hline votarépertu & 3,992 & 3,145 & 167,096 & Campaign \\
\hline catalansvote9N & 1,866 & 1,327 & 165,877 & Campaign \\
\hline independència & 2,036 & 1,455 & 162,591 & Campaign \\
\hline dretadecidir & 1,317 & 1,024 & 150,945 & Campaign \\
\hline $\mathrm{pp}$ & 384 & 327 & 145,509 & Thematic \\
\hline
\end{tabular}

Source: Produced using DMI-TCAT data

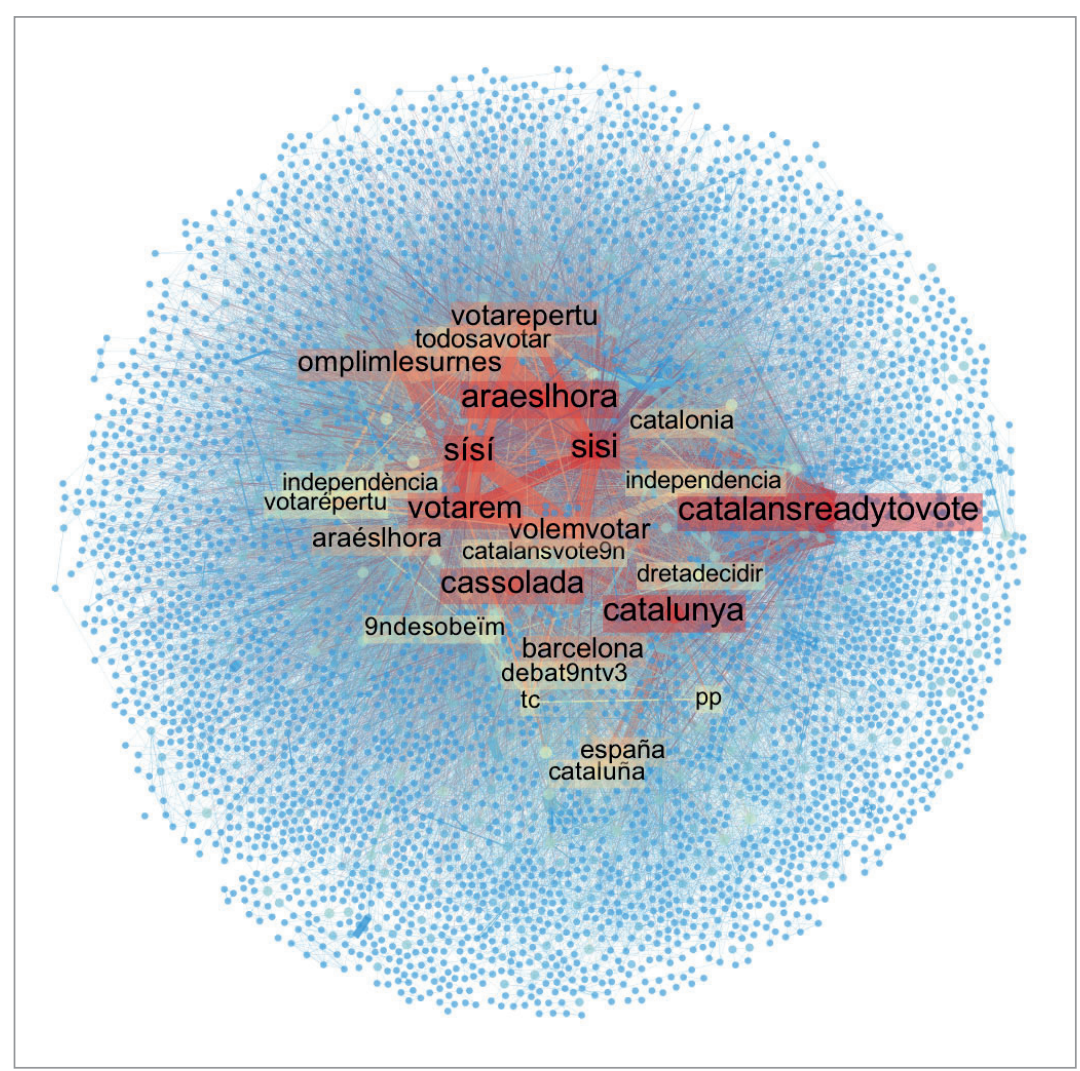

Figure 2. Network of hashtags (04/11-08/11)

\subsection{November 9th}

Table 3, which contains the frequencies and users of the most central hashtags, clearly reflects that voting day was the day of highest publication activity. Following the trend that we saw for the other top $25 \mathrm{~s}$, the 'campaign' hashtags are dominant (14 out of 25), but there is also an increase in the tags used by TV programs as a result of the media interest created by the participative process. \#Omplimlesurnes, which also appeared in the previous period has the highest register of use, with almost 47,000 tweets published by a little over 24,000 different users.

The network of hashtags on November 9 is evidence of the clamorous and festive mood of the day, as emitted by the centrality of hashtags such as \#cataloniawins, \#jojahevotat, \#todosavotar, \#omplimlesurnes, \#hemvotathemguanyat, \#todosavotar, \#araeslhora, \#araéslhora, and \#catalansreadytovote which to an extent can be related to the campaign in favor of the 
Table 3. Top 25 hashtags (09/11)

\begin{tabular}{|c|c|c|c|c|}
\hline Hashtag & Frequency & Users & $\begin{array}{c}\text { Betweenness } \\
\text { centrality }\end{array}$ & Category \\
\hline omplimlesurnes & 46,873 & 24,120 & $3,297,147$ & Campaign \\
\hline catalunya & 7,221 & 5,522 & $2,070,730$ & Thematic \\
\hline hemvotathemguanyat & 26,411 & 15,835 & $2,000,202$ & Campaign \\
\hline sisi & 11,726 & 8,729 & $1,668,845$ & Campaign \\
\hline 9Ntv3 & 29,201 & 16,504 & $1,651,016$ & Media \\
\hline jojahevotat & 17,151 & 12,957 & $1,400,186$ & Campaign \\
\hline cataloniawins & 14,910 & 9,701 & $1,016,362$ & Campaign \\
\hline todosavotar & 21,301 & 15,498 & 977,799 & Campaign \\
\hline 9Nrac1 & 14,855 & 9,494 & 933,488 & Media \\
\hline araeslhora & 7,638 & 5,844 & 887,842 & Campaign \\
\hline sísí & 7,925 & 6,120 & 876,937 & Campaign \\
\hline catalonia & 3,375 & 2,683 & 374,636 & Thematic \\
\hline cataluña & 2,329 & 1,967 & 372,236 & Thematic \\
\hline catalansreadytovote & 3,752 & 3,056 & 333,451 & Campaign \\
\hline democracia & 1,137 & 1,072 & 265,686 & Campaign \\
\hline araéslhora & 2,634 & 2,134 & 260,098 & Campaign \\
\hline independència & 1,239 & 1,088 & 258,817 & Campaign \\
\hline independencia & 1,540 & 1,076 & 253,934 & Campaign \\
\hline españa & 801 & 609 & 230,438 & Thematic \\
\hline barcelona & 1,305 & 1,077 & 221,118 & Thematic \\
\hline berlin & 269 & 227 & 220,278 & Thematic \\
\hline volemvotar & 1,329 & 1,047 & 219,497 & Campaign \\
\hline salvados9N & 4,051 & 3,058 & 212,672 & Media \\
\hline 9Nenxarxa & 951 & 480 & 192,535 & Thematic \\
\hline votar & 629 & 572 & 187,821 & Thematic \\
\hline
\end{tabular}

what we could call a type of trending topic activism in which users, coordinated and with relatively little effort, can contribute significantly to increasing the visibility of a certain topic. We found several tweets which referred to the different trending topics of the moment:

\#OmplimLesUrnes \# 9Nrac1 \#HemVotatHemGuanyat \#9NTV3 Trending Topic watch out

Top 5 of TrendingTopic Spain are from 9N: \#OmplimLesUrnes \#TodosAVotar, \#9Nrac1 \#HemVotatHemGuanyat \#9NTV3

We continue to occupy trending topic sites: 1. \#OmplimLesUrnes 2. \#TodosAVotar 3. \#9Nrac1 4. \#HemVotatHemGuanyat 5. \#9NTV3

The tone and the terms in which the mediation of $9 \mathrm{~N}$ took place are clearly marked by an intense propaganda campaign

\subsection{From November 10 th to November 14 th}

In the top 25 central hashtags for the period in table 4, there is a smaller number of campaign hashtags, which is logical given that the objective of getting people to vote (which most of the campaign activity centred on) had already been achieved. In first position is \#cataloniawins, a tag passed on from voting day whose original purpose was to become a trending topic worldwide. More than an inertial movement, this hashtag also reflects a moment when the story to carry the results of the consultation was being negotiated. This comment also applies to \#hemvotathemguanyat. public consultation and seems to have been created ad hoc for the day itself.

The same as in the previous period, the use of a varied repertoire of slogans indicates that some of them had the objective of achieving the trending topic position. This is the case for \#cataloniawins, as is clear from the first tweet to use the tag, published by user @araeslhora at 7:14 PM:

Ara és l'hora d'enviar el missatge del 9N al món! Catalunya ha votat, ha decidit, ha guanyat! Fem TT \#CataloniaWins! http://t.co/1UWqFoGmdD

(Now is the time to send the message of $9 \mathrm{~N}$ to the world! Catalonia has voted, has decided, has won! Let's make \#CataloniaWins! a TT

This intense activity to achieve trending topics seems to be the trait that best characterizes the network on voting day. It is a phenomenon that indicates an improved version of the low commitment and low intensity activism known as "slacktivism". In this case we are interested in

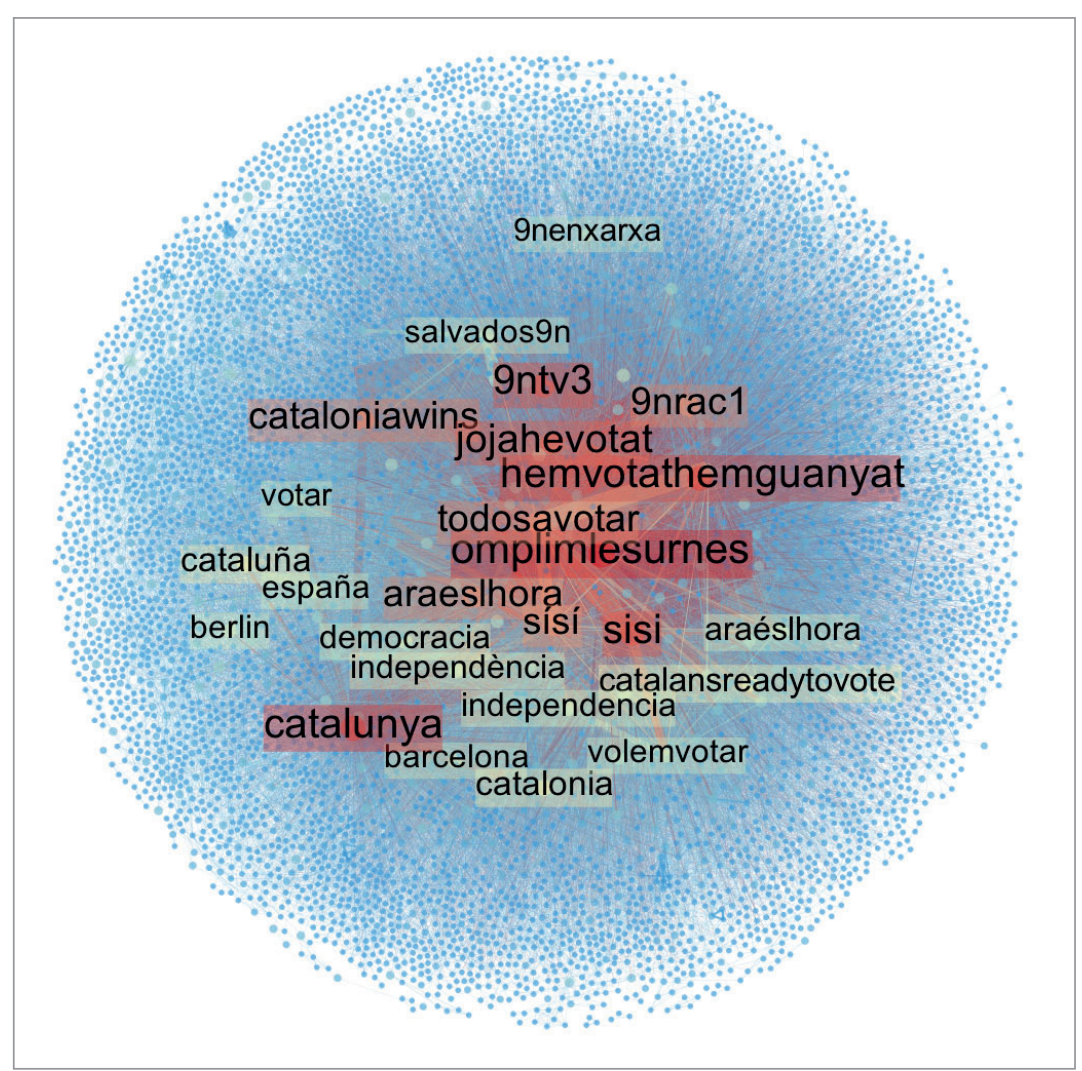

Figure 3. Network of hashtags (09/11) 
Figure 4 shows that, together with \#cataloniawins, there were also several hashtags which were central during most of the periods analyzed, such as: \#sisi, \#sísí, and \#araeslho$\mathrm{ra}$, as well as others inherited from voting day. (\#omplimlesurnes, \#hemvotathemguanyat y \#omplimlesurnas). What this shows is an inertial use of these tags to keep the pro-independence campaign alive.

There is a "trending topic" activism in which users can contribute significantly to increasing the visibility of a certain topic

In that sense it is interesting to point out that the appearance of \#autoinculpacions9N (\#weareallguity9N) was a response to the announcement by the public prosecutor to bring a case against Artur Mas and other members of his government. On the other hand a campaign appeared against the consultation, as seen by the presence of the hashtag \#9Nfrau (\#9Nfraud), which brought together accusations of fraud and other criticism of the consultation. Figure 5 shows in detail the network built up around this hashtag and shows that it was used in conjunction with \#butifarrendum, \#9ncirco, \#9nfail. In this figure, the fact that these hashtags coexisted with others in favour of the consultation and the independence of Catalonia is attributable to the practice described in the theoretical framework and hashtag "hijacking".

Another feature that distinguishes this network is the centrality of tags that referred to TV programs (\#9Ntv3 and \#rajoypost9Narv), which showed the news coverage that the participative process received in the days following November 9 .
Table 4. Top 25 hashtags (10/11 - 14/11)

\begin{tabular}{|c|c|c|c|c|}
\hline Hashtag & Frequency & Users & $\begin{array}{c}\text { Betweenness } \\
\text { centrality }\end{array}$ & Category \\
\hline cataloniawins & 13,135 & 8,652 & $1,002,010$ & Campaign \\
\hline catalunya & 2,565 & 2,098 & 693,593 & Thematic \\
\hline autoinculpacions9N & 8,427 & 4,754 & 415,550 & Campaign \\
\hline sisi & 2,529 & 1,637 & 242,363 & Campaign \\
\hline sísí & 2,294 & 1,730 & 224,274 & Campaign \\
\hline hemvotathemguanyat & 2,199 & 1,759 & 221,167 & Campaign \\
\hline 9Ntv3 & 5,537 & 4,231 & 214,412 & Media \\
\hline cataluña & 3,591 & 3,206 & 195,287 & Thematic \\
\hline catalonia & 1,952 & 1,395 & 185,731 & Thematic \\
\hline rajoy & 1,351 & 1,090 & 178,146 & Thematic \\
\hline araeslhora & 819 & 645 & 169,165 & Campaign \\
\hline omplimlesurnes & 1,973 & 1,679 & 167,957 & Campaign \\
\hline $\mathrm{pp}$ & 392 & 335 & 122,291 & Thematic \\
\hline españa & 664 & 449 & 113,233 & Thematic \\
\hline presidentmas & 2,837 & 1,669 & 112,071 & Campaign \\
\hline arturmas & 556 & 417 & 99,471 & Thematic \\
\hline barcelona & 347 & 270 & 85,993 & Thematic \\
\hline cuba & 31 & 15 & 84,627 & Thematic \\
\hline $10 n$ & 626 & 577 & 76,472 & Thematic \\
\hline 9Nfrau & 2,555 & 1,863 & 64,724 & Campaign \\
\hline fiesta & 3 & 3 & 60,105 & Thematic \\
\hline consulta & 236 & 196 & 57,591 & Thematic \\
\hline noticias & 280 & 117 & 55,300 & Thematic \\
\hline mas & $357 d$ & 295 & 52,904 & Thematic \\
\hline rajoypost9Narv & 1,856 & 1,503 & 51,168 & Media \\
\hline
\end{tabular}

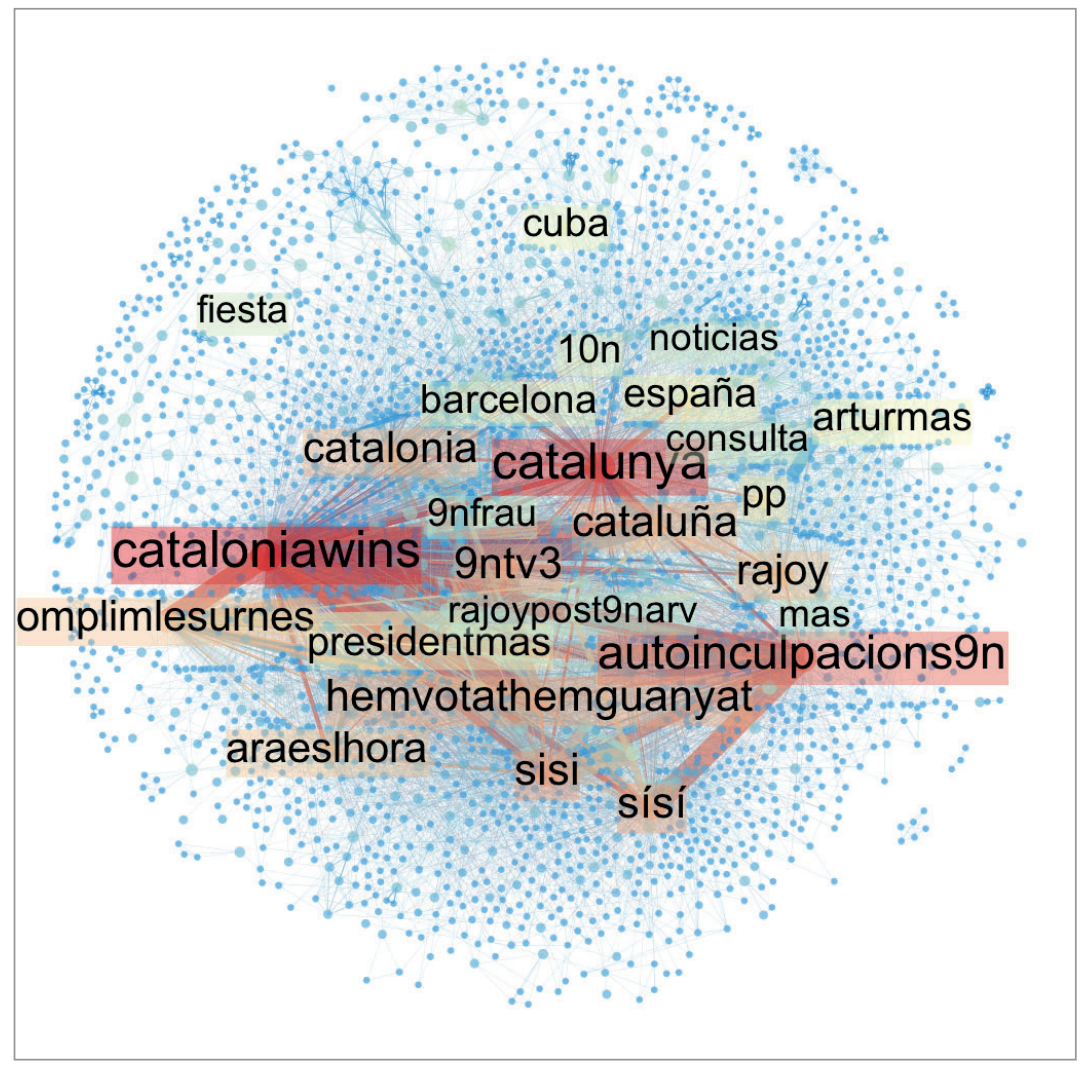

Figure 4. Network of hashtags (10/11-14/11)

\section{Conclusions}

The conclusions of this research are organized in response to the original questions posed:

What are the main traits which distinguish the narrative of the political process of November 9 on Twitter?

The analysis of the results, and more specifically the categorization of the hashtags, offers the conclusion that the trait that most clearly distinguishes the narrative of the participative process of $9 \mathrm{~N}$ was the intensive campaign activity by those in favor of the right to decide and the independence of Catalonia. As seen in most of the periods analyzed, the hashtags fitting into the campaign category were the most prominent, and occupyied more than $60 \%$ of the top positions for betweenness centrality.

The dynamic changed in the days after the voting, when a narrative rivalry can be observed between the opposing ideological opinions to set the story which will 


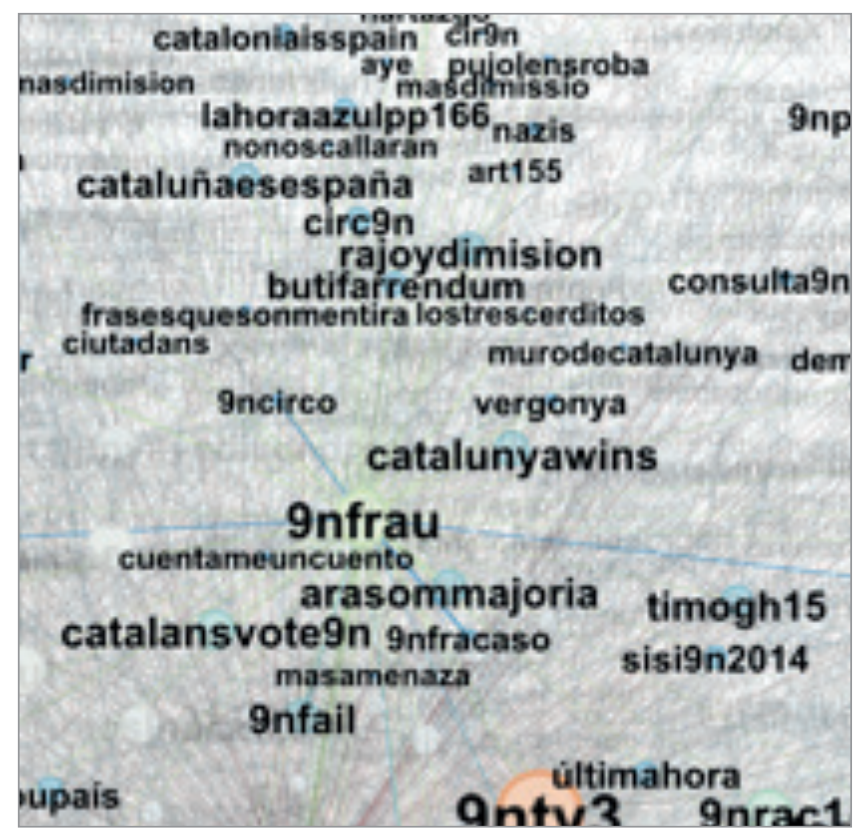

Figure 5. Zoom in \#9Nfrau

impose an evaluation of the participative process as a success or a failure. This confrontation becomes evident with the appearance of hashtag \#9nfrau in the top 25 for centrality at the same time as \#cataloniawins and \#hemvotathemguanyat. It could be argued that this process of negotiation of reading is the result of the clash between the self-government and the unionist campaigns.

In any case, this research clearly reveals that the individuals and organizations supporting sovereignty were more effective when it came to setting the topics and interpretations that dominated the narrative. Data relating to the frequency of use of the hashtags for campaigns in favour of the $9 \mathrm{~N}$ event and the independence of Catalonia, as well as the number of different users who used them (seen in tables 2,3, and 4) support this claim. So much so that on many occasions the unionist reasoning was difficult to observe and was in a clear minority. In a way, we can compare the narrative of $9 \mathrm{~N}$ to an echo chamber in which basically only the independentist message reverberated. This situation can be explained fundamentally because the narrative of $9 \mathrm{~N}$ is not precisely defined by its dialectic dimension given that one of the sides in the dispute decided not to take part, or at least not to do so in the terms proposed by those in favor of self-government. This characteristic has certain parallels with what was, in essence, the participative process of $9 \mathrm{~N}$ : a demand to hold a debate and call into question the political status of Catalonia, which the Government of Spain decided not to take into account and, when the voting took place, those against decided not to participate.

\section{What were the central frames in the narrative of the political process of November 9 on Twitter?}

Our analysis allows us to state that, in general, the topics, interpretations, evaluations and calls for action that occupied the center of the story on Twitter were those from people in favor of the consultation and the independence of Catalonia. From the way in which they appear they can be considered part of the sovereigntist campaign and are normally expressed in the form of support for the consultation more than directly in favour of independence. We also observed how during the days after the voting the rivalry between the opposing ideologies to impose a certain interpretation of the participative process became more evident.

\section{Which strategies were used for the construction of the narrative?}

Analysis of the hashtags occupying a more predominant position in the narrative allows us to see how the emotional and affective element constitutes a recurrent resource which achieves high levels of effectiveness when it came to involving users in favor of the sovereigntist cause. We observed this component in both the tags expressing:

- a desire to vote (\#volemvotar, \#omplimlesurnes, etc.);

- the reaction to the decision of the Constitutional Court (\#desobeïm, \#desobediència, etc.);

- the jubilation after the vote (\#hemvotathemguanyat, \#cataloniawins), and the calls to participate (\#votarépertu).

We were also able to observe the effort made to convert certain hashtags into trending topics. This comes from the fact that the messages encouraging users to participate mentioned the aim of appearing in the list of trending topics. In any case, we believe that it would not be prudent to underestimate the achievement of this challenge given that they have a decisive influence on increasing the visibility and dissemination of the Catalan case.

Another strategy that deserves to be highlighted in the practice of hijacking hashtags by political rivals as counter-propaganda. This activity should be interpreted as a genuine mechanism in the culture of the use of the platform to redefine the interpretative frameworks of the narrative surrounding $9 N$.

In the days following the voting, a narrative rivalry can be observed between the opposing ideological opinions to set the story of the participative process

The analysis of this case has allowed us to demonstrate the value of hashtags as elements used to articulate propaganda (and counter-propaganda) campaigns dealing with political debates. In this context the function of thematic demarcation that the hashtag carries out is displaced by a political use as testified by the ideological load of the most frequently used. They also serve to organize and coordinate the mobilization of the public within the platform - to increase the visibility of the campaigns through the achievement of trending topics, and also on the street- to involve users in protest actions such as caceroladas (pot-banging protests) or to take part in the participative process itself. They therefore become a crucial mechanism for creating and setting the interpretative frameworks around which the story of political conflicts revolves.

Given the importance of social platforms in the hybrid media ecosystem, they become a space where politics, the media and the public compete to disseminate a certain discour- 
se. This story is later incorporated in the traditional media flows and, indirectly, ends of reaching citizens who do not form part of the digital platforms. The weight of each of the different actors in this process is a question that cannot be elucidated using the methods employed for this article, but it is a particularly important aspect that should be addressed in future research.

\section{Bibliography}

Aragón, Pablo; Kappler, Karolin-Eva; Kaltenbrunner, Andreas; Laniado, David; Volkovich, Yana (2013). “Communication dynamics in Twitter during political campaigns: The case of the 2011 Spanish election". Policy \& internet, v. 5, n. 2, pp. 183-116.

https://doi.org/10.1002/1944-2866.POI327

Bastian, Mathieu; Heymann, Sébastien; Jacomy, Mathieu (2009). "Gephi: an open source software for exploring and manipulating networks". In: Proceedings of the Third international conference on weblogs and social media, Icwsm, San José, California (USA), May 17-20, v. 8, pp. 361-362.

https://doi.org/10.13140/2.1.1341.1520

Bennet, W. Lance; Segerberg, Alexandra (2012). "The logic of connective action". Information, communication \& society, v. 15, n. 5, pp. 739-768.

http://ccce.com.washington.edu/about/assets/2012iCSLCA-Bennett\&Segerberg-LogicofConnectiveAction.pdf https://doi.org/10.1080/1369118X.2012.670661

Borge-Holthoefer, Javier; Rivero, Alejandro; García, Iñigo; Cauhé, Elisa; Ferrer, Alfredo; Ferrer, Darío; Francos, David; Iñíguez, David; Pérez, María-Pilar; Ruiz, Gonzalo; Sanz, Francisco; Serrano, Fermín; Viñas, Cristina; Tarancón, Alfonso; Moreno, Yamir (2011). "Structural and dynamical patterns on online social networks: The Spanish May 15th movement as a case study". PLos one, v. 6, n. 8. https://doi.org/10.1371/journal.pone.0023883

Borra, Erik; Rieder, Bernhard (2014). "Programmed method: Developing a toolset for capturing and analyzing tweets". Aslib journal of information management, v. 66, n. 3, pp. 262-268.

https://goo.gl/QWxDFs

https://doi.org/10.1108/AJIM-09-2013-0094

Boyd, Danah; Golder, Scott; Lotan, Gilad (2010). "Tweet, tweet, retweet: conversational aspects of retweeting on Twitter". In: Hawaii intl conf on system sciences (Hiccs), pp. 1-10. https://www.danah.org/papers/TweetTweetRetweet.pdf https://doi.org/10.1109/HICSS.2010.412

Bruns, Axel; Burguess, Jean (2011). "The use of Twitter hashtags in the formation of ad hoc publics". In: Procs of the $6^{\text {th }}$ European Consortium for Political Research (ECPR). General conference 2011, University of Iceland, Reykjavik. http://eprints.qut.edu.au/46515

Bruns, Axel; Etham, Ben (2009). "Twitter free Iran: An evaluation of Twitter's role in public diplomacy and information operations in Iran's 2009 election crisis". Communications policy and research forum, pp. 322-334.

http://vuir.vu.edu.au/15230
Bruns, Axel; Stieglitz, Stefan (2012). "Quantitative approaches to comparing communication patterns on Twitter". Journal of technology in human services, v. 30, n. 3-4. https://eprints.qut.edu.au/55823 https://doi.org/10.1080/15228835.2012.744249

Callon, Michel; Courtial, Jean-Pierre; Turner, William A.; Bauin, Serge (1983). "From translations to problematic networks: An introduction to co-word analysis". Social science information, v. 22, n. 2, pp. 191-235.

https://doi.org/10.1177/053901883022002003

Casero-Ripollés, Andreu (2008). “Modelos de relación entre periodistas y políticos: la perspectiva de la negociación constante". Estudios sobre el mensaje periodístico, v. 14, pp. 111-128.

http://revistas.ucm.es/index.php/ESMP/article/view/ ESMP0808110111A

Casero-Ripollés, Andreu (2015). “Estrategias y prácticas comunicativas del activismo político en las redes sociales en España". Historia y comunicación social, v. 20, n. 2, pp. 535-550. https://doi.org/10.5209/rev_hics.2015.v20.n2.51399

Casero-Ripollés, Andreu (2017). “Producing political content for web 2.0: Empowering citizens and vulnerable populations". El profesional de la información, v. 26, n. 1, pp. 13-19. https://doi.org/10.3145/epi.2017.ene.02

Casero-Ripollés, Andreu; Feenstra, Ramón A. (2012). “The 15-M Movement and the new media: A case study of how new themes were introduced into Spanish political discourse". MIA. Media international Australia, v. 144, n. 1, pp. 68-76.

https://goo.gl/T54z6u

https://doi.org/10.1177/1329878X1214400111

Chadwick, Andrew (2011). "Britain's first live televised party leaders' debate: From the news cycle to the political information cycle". Parliamentary affairs, v. 64, n. 1, pp. 24-44. https://goo.gl/Dsn8kb https://doi.org/10.1093/pa/gsq045

Danowski, James A. (2009). "Inferences from word networks in messages". En: Krippendorff, Klaus; Bock, Mary-Angela. The content analysis reader. Thousand Oaks, California: SAGE Publications, pp. 421-429. ISBN: 9781412949668

Entman, Robert M. (1993). "Framing: Toward clarification of a fractured paradigm". Journal of communication, v. 43, n. 4, pp. 51-58.

https://www.unc.edu/ fbaum/teaching/articles/JCommunication-1993-Entman.pdf https://doi.org/10.1111/j.1460-2466.1993.tb01304.x

Hadgu, Asmelash-Teka; Garimella, Kiran; Weber, Ingmar (2013). "Political hashtag hijacking in the US". In: Proceedings of the $22^{\text {nd }}$ Int l conf on World Wide Web companion. Rio de Janeiro, Brasil, May 13-17, pp. 55-56.

https://goo.gl/fc518C

https://doi.org/10.1145/2487788.2487809

Highfield, Tim (2012). "Taking of many things: Using topical networks to study discussions in social media". Journal of technology in human services, n. 30, pp. 204-219.

https://eprints.qut.edu.au/55509 
https://doi.org/10.1080/15228835.2012.746894

Jacomy, Mathieu; Venturini, Tomasso; Heymann, Sébastien; Bastian, Mathieu (2011). "Forceatlas2, a continous graph layout algorithm for handy network visualization designed for the Gephi software". PLoS one, v. 9, n. 6. https://doi.org/10.1371/journal.pone.0098679

Lotan, Gilad; Graeff, Erhardt; Ananny, Mike; Gaffney, Devin; Pearce, Ian; Boyd, Dannah (2011). "The revolutions were tweeted: Information flows during the 2011 Tunisian and Egyptian revolutions". International journal of communications, v. 5, pp. 1375-1405.

http://ijoc.org/index.php/ijoc/article/view/1246/643

Meraz, Sharon; Papacharissi, Zizi (2013). "Networked gatekeeping and networked framing on \#Egypt". The international journal of press/politics, v. 18, n. 2, pp. 138-166.

http://zizi.people.uic.edu/Site/Research_files/MerazPapacharissi. $p d f$

https://doi.org/10.1177/1940161212474472

McQuail, Dennis (1994). Mass comunication theory: An introduction. London: Sage. ISBN: 9780803977853

Papacharissi, Zizi (2015). Affective publics. New York: Ox- ford Universtiy Press. ISBN: 9780199999736 https://doi.org/10.1093/acprof:oso/9780199999736.001.0001

Papacharissi, Zizi; De-Fatima-Oliveira, Maria (2012). “Affective news and networked publics: The rhythms of news storytelling on \#Egypt". Journal of communication, v. 62, n. 2, pp. 262-282. https://goo.gl/VK5n1t

https://doi.org/10.1111/j.1460-2466.2012.01630.x

Small, Tamara A. (2011). "What the hashtag? A content analysis of Canadian politics". Information, communication \& society, v. 14, n. 6, pp. 872-895.

https://www.researchgate.net/publication/233146925_ What_the_hashtag

https://doi.org/10.1080/1369118X.2011.554572

Van-Dijck, José (2011). "Tracing Twitter: The rise of a microblogging platform". International journal of media and cultural politics, v. 7, n. 3, pp. 333-348.

https://pure.uva.nl/ws/files/1282659/108613_Tracing_ Twitter_MCP_7.3_2_vanDijck.art_edit_pdf.pdf https://doi.org/10.1386/macp.7.3.333_1

Villafañe, Justo; Bustamente, Enrique; Prado, Emilio (1987). Fabricar noticias: las rutinas productivas en radio y televisión. Barcelona: Mitre. ISBN: 8476520271

\section{Colección EPI Scholar}

\section{Libros científicos de Información, Documentación y Comunicación}

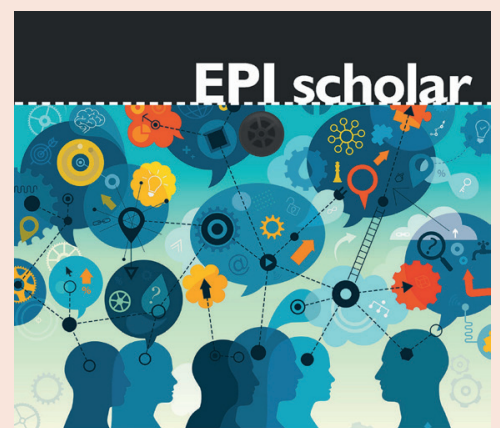

DESAFÍO A LA INVESTIGACIÓN ESTÁNDAR EN COMUNICACIÓN CRÍTICA Y ALTERNATIVAS

MANUEL GOYANES

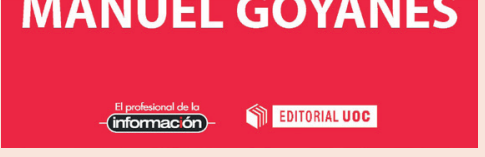

\section{Desafío a la investigación estándar en comunicación. Crítica y alternativas de Manuel Goyanes}

La investigación estándar es la visión legítima y comúnmente aceptada de lo que se considera científico. Es, a grandes rasgos, la buena ciencia. Un tipo de ciencia aplaudida por todos y de la que (casi) todos recogemos sus frutos: permite incrementar la productividad, adquirir estatus y, finalmente, notoriedad y acreditaciones. La investigación estándar es algo natural y racional, aunque también el principal factor de deshidratación intelectual de nuestro campo: inunda la investigación con formas y expresiones formularias, silencia la pluralidad de aproximaciones y fomenta el especialismo hasta lo absurdo.

Este libro aborda frontalmente la problemática de la estandarización y sus implicaciones científico-sociales. A través de su lectura, el lector descubrirá cuáles son las normas y valores que regulan la producción de conocimiento, qué hay detrás de la tierra incógnita de nuestras prácticas y disposiciones científicas y cómo desarrollar un tipo de investigación más imaginativa y original. A lo largo de sus páginas muestra cómo es posible pensar e investigar de modo alternativo a través de la problematización de lo dado por sentado, el estilo narrativo y la provocación.

El libro es una llamada de atención para salir de nuestro estado de confort actual. Anima a los investigadores a retar lo establecido y a alcanzar notoriedad e impacto mediante ideas y teorías desafiantes

Goyanes, Manuel (2017). Desafío a la investigación estándar en comunicación. Crítica y alternativas. Barcelona: El profesional de la información, Editorial UOC, colección EPI Scholar n. 7, 164 pp. ISBN: 97884 91166757
Información: Isabel Olea

epi.iolea@gmail.com

http://www.elprofesionaldelainformacion.com/librosEPIScholar.html 